\title{
InTERACTIONS BETWEEN FISH RESOURCES AND CORMORANTS Phalacrocorax carbo In THE GRADO AND MARANO LAGOON (NE ITALY)
}

\section{Interakcije med ribogojništvom in kormorani Phalacrocorax carbo v lagunah Grado in Marano (SV Italija)}

\author{
Mauro Cosolo, Paolo Utmar, Flavio Roppa \& Stefano Sponza \\ University of Trieste, Department of Life Sciences - CSEE (Centre of Etho-Ecological Studies), via Giorgieri 9, \\ I-34127 Trieste, Italy, e-mail: cosolomauro@inwind.it; paolo.utmar@libero.it; roppaflavio@hotmail.com; \\ sponza@units.it
}

\begin{abstract}
The aim of this study was to determine the importance of different environments for Cormorant Phalacrocorax carbo biology in the Grado and Marano lagoon (Friuli Venezia Giulia, NE Italy, Upper Adriatic Sea), and to estimate the levels of fish removal within such areas. Data were collected on Cormorant abundance and the amount of fish consumed in two fishing valli (Valle Noghera and Valle Artalina) and in three tidal areas (Goppion, Cavanata sea, Grado and Marano lagoon). The number of Cormorants per 100 ha was relatively low in all the study areas. The highest density of feeding cormorants in November (24 birds/100 ha) was in Valle Noghera. The latter is ascribed to an isolated event of 50 birds in social fishing activity. During the rest of the November survey time ( $72 \%$ of the total), lower densities were noted (2.5 birds/100 ha). Fish consumption was also relatively low. In Valle Artalina the maximum was $6.8 \mathrm{~kg} / 100$ ha in December. The highest fish consumption was estimated in Valle Noghera in November $(41.9 \mathrm{~kg} / 100 \mathrm{ha})$ and in the Grado and Marano lagoon in January $(7.6 \mathrm{~kg} / 100 \mathrm{ha})$. In fish farms, the highest fish consumption is recorded in November and December, exclusively within wintering basins and canals. So these areas should be covered with wire nets. Furthermore, considering the high variability and irregularity of fish removal, the use of active deterring methods (e.g. gas cannons) can give good results, especially if applied during social fishing events.
\end{abstract}

Key words: interactions, fisheries, Cormorant, Phalacrocorax carbo, Grado, Marano, lagoon

Ključne besede: interakcije, ribogojništvo, kormoran, Phalacrocorax carbo, Grado, Gradež, Marano, laguna

\section{Introduction}

The fish ponds (fishing "valli«) system of Grado and Marano lagoon (NE Italy, Upper Adriatic Sea) covers a total surface of about 1720 hectares, of a total area of 20,000 ha of coastal wetlands (GIORDA 1990). Within Grado lagoon there are 38 fishing valli (1,400 ha), and in Marano 17 (320 ha; SCARELli \& Venturi 200I). In Marano they are small and intensively managed. Grado fishing valli are larger and extensively managed, so water occupies on average $80 \%$ of the total surface. The most important species reared are European seabass
Dicentrarchus labrax, the Gilthead seabream Sparus aurata, the Big-scale sand smelt Atherina boyeri, Mullets Mugilidae and the European eel Anguilla anguilla.

In recent decades an important decline of this activity has been observed, in terms of productivity $(50 \mathrm{~kg}$ of fish/ha), compared to the production by the fishing valli in Caorle lagoon $(80 \mathrm{~kg} / \mathrm{ha})$ and, especially, the valli in Venice lagoon (100-150 kg/ha) (GIORDA I990). This decline could be associated both to the increase of more rewarding activities (i.e. Mollusc culture) and to the depredation of stocked fish by fish-eating birds (Lanari \& Ballestrazzi 1988, Giorda I992). 
The number of fish-eating bird species in Friuli Venezia Giulia wetlands, either throughout the year or during part of it, is 67 (Cosolo et al. 2006). In particular, in the fishing valli there is a total of 41 species, of which 27 are regularly present. The gradual increase of these species' populations has led to a growing number of conflicts with commercial fisheries all across Europe (EIFAC 1989, Marquiss \& Carss 1994, Feltham et al. 1999).

The Cormorant Phalacrocorax carbo is regarded as the one with the highest impact, in terms of fish removal and of indirect effects, such as death of fish caused by thermal shock due to birds' incursions in wintering tanks and consequent injuries incurred by fish (WWF Italia 2000). The Cormorant population wintering in Friuli Venezia Giulia wetlands increased steadily from 1989 until the maximum observed in January 2001 (2,366 birds). Thereafter, the numbers decreased and, during the subsequent four winters, stabilized at about 1,700 birds (data from the IWC census, Ufficio Studi Faunistici, Friuli Venezia Giulia Region). The gradual increase of the species and claims from stakeholders have led the regional administration to authorize some abatements, after checking the ineffectiveness of ecological damage prevention systems and following approval by the National Institute for Wild Fauna (INFS). In the winter 2005/2006 a total of 198 shots were authorized, 142 in 2006/2007 and 103 in 2007/2008 (ZANETTI et al. 2007).

The presence of Cormorants in the fishing valli could be affected both by environmental characteristics and by the structure of ponds. The most important factors appear to be the location, size and water depth of fishing basins. Stocking density and behaviour of reared fish could also play an important role (Boldreghini et al. i99i, Perco et al. I994, McKay et al. 2003). Diet analysis in the Grado lagoon (Privileggi 2000) has highlighted that the main prey are, in terms of biomass, the Mullets (52.4\%) and the Flounder Platichthys flesus (17.2\%). The consumption of more important commercial species, such as European seabass and Gilthead seabream, is limited to $5.9 \%$ and $4.1 \%$ respectively of the total biomass.

In this study we have aimed to estimate the fish consumption by the Cormorant on fishing valli and tidal areas of the Grado and Marano lagoon.

\section{Methods}

In order to highlight the seasonal Cormorant population, we monitored monthly all 12 roosts in the coastal wetlands of Friuli Venezia Giulia between August 2006 and July 2007 (Figure 1). Censuses were carried out at dusk on a single day or, if not possible, on consecutive days, in order to avoid overestimation of the population.

We also collected data on Cormorant presence and abundance in four focal areas, namely 1 ) the inshore area in front of Valle Cavanata ("Cavanata sea«, 164 ha), 2) a sector of the Grado lagoon (»Goppion«, 161 ha), 3) a part of a low-production fishing valli (»Valle Artalina", $27 \mathrm{ha}$ ) and 4) a high-production fishing valli ("Valle Noghera«, 65 ha). These areas were chosen in order to have an ecological gradient, from areas with natural presence of fish species to areas characterised by semi-intensive fish farming. From September 2004 to April 2005 dawn to dusk surveys were carried out once a month in each study area. During each census 1 to 3 surveyors recorded, every $30 \mathrm{~min}$, all Cormorants resting and foraging in the area.

Moreover, we performed monthly surveys along a fifth area, the "Grado and Marano lagoon", along a transect (»lagoon transect «), carried out from Grado to Lignano (Figure 1). Along the transect we monitored, twice a day (at high and low tide), 10 sites (total area of 1,346 ha), chosen as their ecological features were representative of the entire lagoon area (about 16,000 ha). At each site two observers recorded for 10 minutes all birds resting and foraging. Monitoring was performed using either a telescope $20-60 x$ or a binocular 8-10x. The evaluation of fish consumption ( $\mathrm{kg} / 100 \mathrm{ha})$ in the five study areas was obtained by integrating the following data:

a) Cormorant density. In the four focal areas (Cavanata sea, Goppion, Valle Artalina and Valle Noghera) we calculated, every $30 \mathrm{~min}$, the density $\left(D_{1}\right)$ of foraging Cormorants, dividing the number of birds by the surface area (ha). At each site of the Grado and Marano lagoon we calculated the density of foraging Cormorants on the basis of 10 min surveys $\left(\mathrm{D}_{2}\right)$.

b) Mean weight of a potential prey. These data were obtained by the analysis of 459 pellets (VolPONI I994, Privileggi 2000), collected monthly (2006/2007) in the most important night roosts. We divided the monthly biomass by the number of prey items. For Grado and Marano lagoon, Cavanata sea and Goppion $\left(\mathrm{W}_{1}\right)$ we considered Flounder, Gobiidae species, Mullets, Gilthead seabream and European seabass to be the most important prey species $(83.1 \%$ of the total biomass) (Cosolo et al. 2007). For the fishing valli (Noghera and Artalina) $\left(\mathrm{W}_{2}\right)$ we analysed only the data of the reared species: Mullets, Gilthead seabream and European seabass.

c) Capture rate (no. of prey/min). From the video recording of 230 foraging Cormorants (Cosolo 




Figure 1: Study area

Slika 1: Območje raziskave

2006), we calculated a value of 0.19 prey $/ \mathrm{min}$ for Flounders, a »benthic" prey, and 0.07 prey $/ \mathrm{min}$ for Mullets, a "pelagic" prey. Flounders and Mullets are the most important prey species in the coastal wetlands of Friuli Venezia Giulia (Cosolo et al. 2007). We assigned the value of $0.07 \mathrm{prey} / \mathrm{min}$ also to Gilthead seabream and European seabass, given their similar ecology and behaviour to those of Mullets, whereas the value of $0.19 \mathrm{prey} / \mathrm{min}$ was similarly assigned to Gobiidae species (»benthic" like Flounders). The monthly mean predation rate for the Grado and Marano lagoon, Cavanata sea and Goppion $\left(\mathrm{P}_{1}\right)$ was determined by the sum of the predation rate of each prey species weighted by the frequency of the species in the pellets. In fishing valli (Noghera and Artalina), given the exclusive presence of "pelagic" species, we applied always the value of $0.07 \mathrm{prey} / \mathrm{min}\left(\mathrm{P}_{2}\right)$.

For each area we then calculated the fish consumption $(\mathrm{kg} / 100 \mathrm{ha})$ for every half hour in the Cavanata sea $\left(\mathrm{C}_{1}\right)$, Goppion $\left(\mathrm{C}_{1}\right)$, Valle Artalina $\left(\mathrm{C}_{2}\right)$, Valle Noghera $\left(\mathrm{C}_{2}\right)$ and for every $10 \mathrm{~min}$ in the Grado and Marano lagoon sites $\left(\mathrm{C}_{3}\right)$ using the formulas:

\section{Goppion and Cavanata sea:}

$$
\mathrm{C}_{1}=\mathrm{D}_{1} \times\left[\left(\mathrm{P}_{1} \times 30\right) \times \mathrm{W}_{1}\right]
$$

Valle Artalina and Valle Noghera:

$$
\mathrm{C}_{2}=\mathrm{D}_{1} \times\left[\left(\mathrm{P}_{2} \times 30\right) \times \mathrm{W}_{2}\right]
$$

Grado and Marano lagoon:

$$
\mathrm{C}_{3}=\mathrm{D}_{2} \times\left[\left(\mathrm{P}_{1} \times 10\right) \times \mathrm{W}_{1}\right]
$$

Finally the "daily fish consumption" (kg/100 ha) for each month in the Cavanata sea, Goppion, Valle

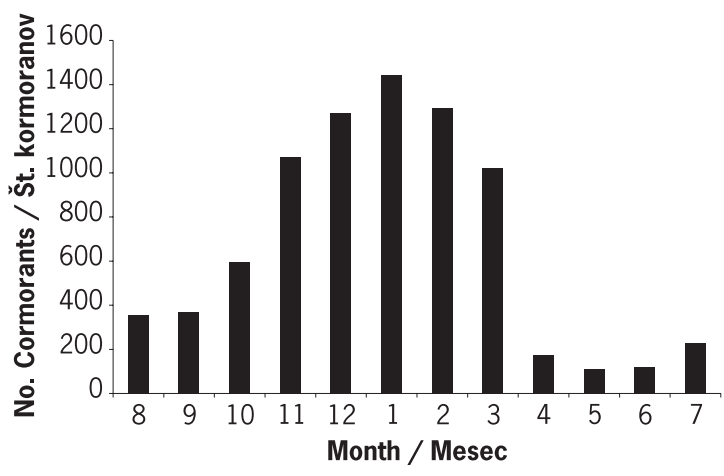

Figure 2: Number of Cormorants Phalacrocorax carbo in the coastal wetlands of Friuli Venezia Giulia (NE Italy) in the years 2006/2007

Slika 2: Število kormoranov Phalacrocorax carbo v obalnih mokriščih Furlanije Julijske krajine (SV Italija) v letih $2006 / 2007$

Artalina, and Valle Noghera was obtained from the sum of $\mathrm{C}_{1}$ and $\mathrm{C}_{2}$, considering that the number of half hours varied through the season, and in the Grado and Marano lagoon from the sum of $\mathrm{C}_{3}$ values multiplied by a conversion factor to reach the daily consumption.

\section{Results}

More Cormorants on roosts were recorded from December to February. In August and September numbers were stable. The population increased from October, with a peak in January. The subsequent 


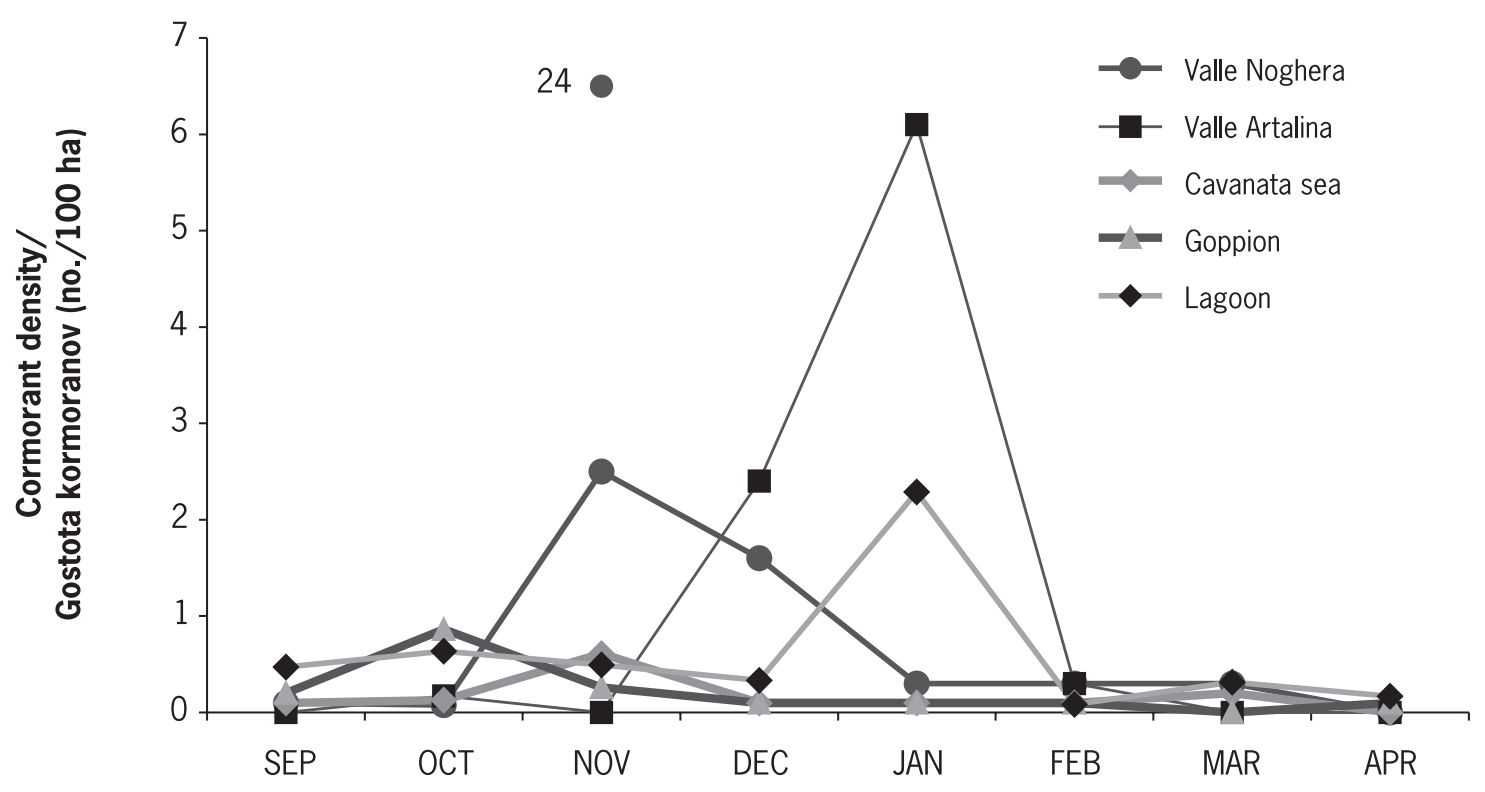

Figure 3: Monthly density of foraging Cormorants Phalacrocorax carbo in the five study areas

Slika 3: Mesečna gostota prehranjujočih se kormoranov Phalacrocorax carbo v petih območjih raziskave

progressive decrease, due to reproductive migration, resulted in the lowest numbers in May and June (Figure 2).

The number of foraging Cormorants/100 ha was relatively low in all the study areas (Figure 3). Valle Noghera was characterized by the highest density of feeding cormorants in November ( 24 birds/100 ha). This figure resulted from an isolated event of 50 birds in social fishing activity, that lasted less than 2 hours. During the rest of the survey time ( $72 \%$ of the total) lower densities (2.5 birds/100 ha), were noted, in accord with the other months (Figure 3). In January we observed an increase in Valle Artalina and in the Grado and Marano lagoon. In September-October and March-April the highest densities were observed in the lagoon areas.

Fish consumption was relatively low every month in all the study areas (Figure 4), and depended on bird densities. In September, October and April the highest values were observed in the lagoon areas. In Valle Artalina the maximum was $6.8 \mathrm{~kg} / 100$ ha in December. The highest fish consumption was estimated in Valle Noghera in November (41.9 kg/100 ha) and in the Grado and Marano lagoon in January $(7.6 \mathrm{~kg} / 100 \mathrm{ha})$ (Figure 4). The highest values in November in Valle Noghera and January in Grado and Marano lagoon are ascribed to a temporary social foraging activity, with the lowest values corresponding to the values registered during the rest of the survey time (Figure 4).

\section{Discussion}

The Cormorant population in the coastal area of Friuli Venezia Giulia reached a peak in January 2007. In previous winter seasons (2004/2005 and 2005/2006), we observed a maximum in February (Cosolo et al. 2006). Probably the high mean temperatures recorded during winter 2006/2007 favoured their presence and possibly advanced the reproductive migration to the northern European nesting areas. Moreover, the mean temperature of air and sea water was higher than in the previous 10 years (METEO FVG 2007). Nearly all the Cormorants utilised a single roost in the Grado lagoon (Valle Gorgo) for summering.

The presence of foraging individuals at the fishing valli was not constant throughout the winter. Long periods of relatively low presence or even absence were recorded, alternating with periods marked by episodic incursions of large numbers of birds. The densities of Cormorants observed in this study (nearly always less than 6 birds/100 ha) are in agreement with previous studies carried out in Friuli Venezia Giulia and Veneto Regions (Cherubini et al. 1993, Perco et al. I994, WWF Italia 2000). These are, to our knowledge, the smallest density values when compared with other Italian wetlands, where the species reached mean values of 1.2 birds/ha (BACCETti \& CoRBi I988). Fish consumption was also quite low, given that in the fishing valli of Venice lagoon fish removal of 8.2 




Figure 4: Daily fish consumption estimates by Cormorants Phalacrocorax carbo (kg/100 ha) in the 5 study areas

Slika 4: Ocena dnevne količine zaužitih rib za kormorane Phalacrocorax carbo v petih območjih raziskave (kg/100 ha)

$\mathrm{kg} / \mathrm{ha}$ was calculated (by a different methodology) (Cherubini 1996). In our study the highest value $(41.9 \mathrm{~kg} / 100 \mathrm{ha})$ was recorded in November in Valle Noghera, where up to 50 birds were involved in social fishing activity. We suggest that this behaviour is linked to farm management procedures. Usually, during autumn, farmed fish are moved into wintering tanks and collection basins, in this way creating water bodies with unusually high densities of fish. If these tanks are not properly protected, Cormorants can cause huge damage in terms of fish removal (Draulans i988, Melotti et al. 1993, Donati et al. 1995, Dieperink 1995, Melotti et al. 1996, Donati et al. 1997, Feltham et al. 1999). We believe that the impact could be drastically reduced if tanks used for intensive fish farming were properly protected. At present, the most effective system of protection is to cover water bodies with wire nets (CARSS 2003). Furthermore, the use of active deterrent methods, like fires in salvoes and gas cannons, can give good results (IM \& HAFNER I985), since the impact is irregular. The action could be maximized when social foraging occurs (VolPONi \& Rossi 1998). Moreover, the focused abatements should be planned only in November and December, the most critical period, and only within impacted fish farms. Nevertheless, the low efficacy of this mitigation measure (abatements) has been demonstrated (Marquiss \& Carss 1994, Mellin \& MirowsKa-Ibron 1997, McKay et al. I999, Marion
2003). Our results suggest that, in the early autumn (September and October) and spring (April), when climatic conditions are better, the most important feeding grounds are the lagoon areas (Goppion, Cavanata sea and Grado and Marano lagoon).

Acknowledgments: We thank Dr. Nicoletta Privileggi for pellet analysis, the Corpo Forestale of Friuli Venezia Giulia Region, and in particular Lt. Alessandro Macuzzi, for the first performance of the "lagoon transect « by boat. We are grateful to Michele Tofful, Barbara Cimador and Christian Trani for help in the field and to the Ufficio Studi Faunistici of Friuli Venezia Giulia Region for data and support. This study provides an update on the results presented in Work Package 4 - Action 1 "Sustainable fruition of transitional ecosystems. Transnational studies on sustainable development in protected transitional areas: fisheries exploitation" of the CADSES Project "Management and sustainable development of protected transitional waters", granted to and under the scientific supervision of Enrico A. Ferrero.

\section{Povzetek}

Pričujočo raziskavo so avtorji prispevka opravili z namenom, da ugotovijo pomen različnih okolij za biologijo velikega kormorana Phalacrocorax carbo $\mathrm{v}$ območju lagun Grado in Marano (Benečija Julijska krajina, SV Italija, zgornji Jadran) in ocenijo količino 
M. Cosolo, P. Utmar, F. Roppa \& S. Sponza: Interactions between fish resources and Cormorants Phalacrocorax carbo in the Grado and Marano lagoon

rib, ki jih tu pojedo te ribojede ptice. V petih območjih, in sicer dveh ribogojnicah (Valle Noghera in Valle Artalina) in treh bibavičnih območjih (Goppion, Cavanata, lagunah Grado in Marano), so bili zbrani podatki o številčnosti velikih kormoranov in količini zaužitih rib. Število kormoranov na 100 ha je bilo v preučevanih območjih razmeroma nizko. Značilnost Valle Noghera je bila, da je bila najvišja gostota prehranjujočih se kormoranov dosežena $\mathrm{v}$ mesecu novembru (24 osebkov/100 ha), kar gre pripisati posameznim dogodkom, ko je kakih 50 osebkov sodelovalo v skupnem ribolovu. $\mathrm{V}$ preostalem času popisa v novembru ( $72 \%$ skupnega časa) so avtorji zabeležili manjše gostote kormoranov (2.5 osebka/100 ha). Tudi količina pojedenih rib je bila razmeroma nizka. VValle Artalina je bil maksimum (6.8 kg rib/100 ha) dosežen meseca decembra, v Valle Noghera (41.9 $\mathrm{kg} / 100 \mathrm{ha}$ ) novembra, in v lagunah Grado in Marano $(7.6 \mathrm{~kg} / 100 \mathrm{ha})$ pa meseca januarja. $\mathrm{V}$ ribnikih pojedo veliki kormorani največ rib novembra in decembra, pri čemer niso upoštevani bazeni, $\mathrm{v}$ katerih kormorani prezimujejo, in kanali. Ribogojnice bi tako morale biti prekrite $\mathrm{z}$ žičnatimi mrežami. Upoštevaje veliko spremenljivost in nerednost glede odvzema rib avtorji zato menijo, da bi lahko bile učinkovite aktivne metode plašenja (npr. plinski topovi), še posebno med skupinskim ribolovom.

\section{References}

Baccetti, N. \& Corbi, F. (I988): Lo svernamento del cormorano in Italia. Note Conclusive. - In: BACCETTI, N. (ed.): Lo svernamento del cormorano in Italia. Suppl. Ric. Biol. Selvaggina 15: 151-155.

Boldreghini, P., Tinarelli, R. \& Rizzoli, M. (i99i): Distribuzione spazio-temporale di uccelli ittiofagi in un'area della pianura Padana ed implicazioni gestionali. - Suppl. Ric. Biol. Selvaggina 19: 73-90.

Carss, D.N. (ed.) (2003): Reducing the conflict between Cormorants and fisheries on a pan-European scale. Report to the European Commission (REDCAFE final report). - CEH, Banchory.

Cherubini, G. (1996): Composizione della dieta ed entità del prelievo del Cormorano in Laguna di Venezia. pp. 4053 In: Atti del Convegno Interregionale »Il Cormorano nelle lagune venete«, San Donà di Piave, 23 Aprile 1996, Provincia di Venezia, Assessorato alla Caccia, Pesca, Vigilanza e Protezione civile.

Cherubini, G., Manzi, R. \& Baccetti, N. (1993): La popolazione di Cormorano Phalacrocorax carbo sinensis svernante in Laguna di Venezia. - Riv. Ital. Ornitol. 63 (1): 41-54.

Cosolo, M. (2006): Interazioni tra avifauna ittiofaga ed attività produttive nella laguna di Grado e Marano. PhD thesis, Università degli Studi di Trieste.
Cosolo, M., Utmar, P., Roppa, F. \& Sponza, S. (2006): Interaction between waterbirds and productive activities in the Grado and Marano lagoon: the case of the Great cormorant. - Atti del Workshop Tecnico »Gestione dei siti della rete Natura 2000 in ambienti di transizione», 7-9 giugno 2006, Grado (GO). - Edizioni Università di Trieste, EUT.

Cosolo, M., Utmar, P., Privileggi, N., Roppa, F., Facchin, G., Fattori, U. \& Sponza, S. (2007): Il Cormorano (Phalacrocorax carbo) in Friuli Venezia Giulia. - Poster. XIV Convegno CIO, 26-30 Settembre 2007, Trieste (Italy).

Dieperink, C. (I995): Depredation of commercial and recreational fisheries in a Danish fjord by Cormorants Phalacrocorax carbo sinensis. - Fisheries Management and Ecology 2: 197-207.

Donati, F., Cossutta, G. \& Roncarati, A. (I995): L'impatto dell'avifauna ittiofaga su allevamenti intensivi di Branzino (Dicentrarchus labrax): danno economico e convenienza della copertura dei bacini. - Suppl. Agribusiness Management \& Ambiente 2: 26-31.

Donati, F., Cossutta, G., Roncarati, A. \& Loro, F. (1997): The impact of fish eating birds on intensive Sea bass (Dicentrarchus labrax) farms: economic losses and benefits of covering the ponds. - Suppl. Ric. Biol. Selvaggina 26: 413-424.

Draulans, D. (1988): Effects of Fish-eating Birds on Freshwater Fish Stocks: An Evaluation. - Biol. Cons. 44: 251-263.

EIFAC (1989): Report of the EIFAC Working Party on prevention and control of bird predation in aquaculture and fisheries operations. EIFAC Technical Paper 51. FAO, Rome.

Feltham, J.M., Davies, J.M., Wilson, B.R., Holden, T., Cowx, I.G., Harvey, J.P. \& Britton, J.R. (I999): Case Studies of the Impact of Fish-Eating Birds on Inland Fisheries in England and Wales. Report to the Ministry of Agriculture, Fisheries and Food; project VC 0106, 406 pp.

Giorda, M. (I990): Il Parco Regionale della Laguna di Grado e Marano. - Quaderni dell'Istituto di Geografia della Facoltà di Economia e Commercio dell'Università di Trieste, Trieste.

Giorda, M. (I992): Piano di Conservazione e Sviluppo del Parco naturale della laguna. - Fase di analisi. Aspetti socioeconomici. Regione Autonoma Friuli Venezia Giulia.

IM, B.H. \& HAFNER, H. (1985): Impact des oiseaux piscivores et plus particulièrement du Grand Cormoran (Phalacrocorax carbo) sur les exploitation piscicoles en Camargue. Bulletin Mensuel Office National Chasse 94: 30-36.

LANARI, D. \& BAllestrazzI, R. (1988): La vallicoltura nelle lagune di Grado e Marano. - Periodico mensile della Consulta per l'Agricoltura e le Foreste delle Venezie. Vol. XLII: Fasc. 3.

MARION, L. (2003): Recent development of the breeding and wintering population of Great cormorants (Phalacrocorax carbo) in France. Preliminary results of the effects of a management plan of the species. - Vogelwelt 124: 35-40.

Marquiss, M. \& Carss, D.N. (1994): Avian Piscivores: Basis for Policy. R\&D Report 461/8/NandY. - Natural Rivers Authority, Bristol, 104 pp. 
McKay, H.V., Russell, I.C., Parrot, D. \& Watola, G. (I999): Study of Fish-eating Birds on the Rivers Ouse, Yorkshire. - Report to the Environment Agency, 51 pp.

McKay, H.V., Russell, I.C., Rehfisch, M.M., Armitage, M., Packer, J. \& Parrott, D. (2003): Pilot trials to assess the efficacy of fish refuges in reducing the impact of Cormorants on inland fisheries. In: Cowx I.G. (ed.): Interactions between fish and birds: Implications for Management. - Blackwell Science, Fishing New Books.

Mellin, M. \& Mirowska-Ibron, I. (I999): Population trends of the Great Cormorant (Phalacrocorax carbo) in the north-eastern part of Poland: 1993-1999. $-5^{\text {th }}$ International Conference on Cormorants, December 2000, Freising, Germany.

Melotti, P., Loro, F. \& Impiccini, R. (I993): Impatto della predazione ornitica sull'allevamento intensivo del Branzino (Dicentrarchus labrax). - Rivista Italiana Acquacoltura 28: 17-23.

Melotti, P., Roncarati, A., Dees, A. \& Mordenti, O. (1996): Impact of bird predation on the intensive rearing of Seabass and Seabream. - International Workshop on Seabass and Seabream Culture: Problems and Prospects, Verona, October 16-18.

METEO FVG (2007): Bollettino dell'OSMER, Osservatorio Meteorologico Regionale del Friuli Venezia Giulia. - $\mathrm{N}^{\circ}$ 1, gennaio 2007. [www.meteo.fvg.it].

Perco, F., Tirelli, E., Tinarelli, R., Kravos, K., Santolini, R., Utmar, P. \& Zanutto, I. (1994): Impatto da specie ittiofaghe e metodi per la salvaguardia della produzione ittica e della fauna selvatica in aree lagunari del Friuli Venezia Giulia. - Rapporto per l'Osservatorio Faunistico del Friuli Venezia Giulia, Udine.

Privileggi, N. (2000): Great Cormorants (Phalacrocorax carbo sinensis) wintering in Friuli Venezia Giulia, Northern Adriatic: specific and quantitative diet composition. Vogelwelt 124 (suppl.): 237-243.

Scarelli, M. \& Venturi, G. (eds.) (200I): The Wetlands Project: integrated management of wetlands. Final Report. - Regione Emilia Romagna Assessorato Agricoltura, Ambiente e Sviluppo Sostenibile. Compositori Industrie Grafiche, Bologna.

Volponi, S. (1994): Ecologia del Cormorano Phalacrocorax carbo sinensis (Aves, Pelecaniformes) nel Delta del fiume Po. - PhD Thesis, Università di Ferrara.

Volponi, S. \& Rossi, R. (I998): Predation by piscivorous birds in extensive aquaculture: damage evaluation and trials of non-lethal dissuasion. - Biol. Mar. Medit. 5 (3): 1375-1384. (in Italian)

WWF Italia (2000): Report "Integrated Management of Wetlands". Studio sull'avifauna ittiofaga della fascia costiera del Friuli Venezia Giulia con particolare riferimento alle lagune di Grado e Marano. Analisi delle problematiche socio-economiche. A cura di: ChitTaro S., Guzzon C., Kravos K., Privilleggi N., Tomasi F., Utmar P., Verginella L. \& Zucca P. - Regione Autonoma Friuli Venezia Giulia, Azienda dei Parchi e delle Foreste Regionali, Servizio Conservazione della Natura, Udine.
Zanetti, M., Cosolo, M., Facchin, G., Fattori, U., Rucli, A. \& Sponza, S. (2007): Great cormorant conflict management in Friuli Venezia Giulia, NE Italy. - Proceedings of the "INTERCAFE Case study 2: Extensive aquaculture systems and relationships between stakeholder perspectives and different spatial scales and institutional levels, Po Delta, Italy«. Albarella (FE), 2123 September 2007.

Arrived / Prispelo: 5.6.2008

Accepted / Sprejeto: 5.8.2009 